\title{
Risk factors for myocardial infarction in young women
}

\author{
J. I. MANN, RICHARD DOLL, MARGARET THOROGOOD, M. P. VESSEY, AND \\ W. E. WATERS*
}

Departments of Social and Community Medicine and the Regius Professor of Medicine, University of Oxford, and Department of Community Medicine, University of Southampton*

\begin{abstract}
Mann, J. I., Doll, R., Thorogood, M., Vessey, M. P., and Waters, W. E. (1976). British Journal of Preventive and Social Medicine, 30, 94-100. Risk factors for myocardial infarction in young women. Seventy-seven women discharged from hospital with a diagnosis of myocardial infarction and 207 control patients were investigated. All were under 45 years of age at the time of admission. Heavy cigarette smoking, reported treatment for pre-eclamptic toxaemia, and type II hyperlipoproteinaemia were found to be independent risk factors for myocardial infarction. Reported treatment for hypertension and diabetes are probably also independently associated with subsequent development of the condition, but the associations between myocardial infarction and reported treatment for obesity and psychiatric illness appear to be secondary. Previous publications have suggested that use of oral contraceptives is an independent risk factor. Examination of the effect of several factors combined, suggests that they act synergistically, the presence of three or more factors increasing the risk 128 -fold.
\end{abstract}

We have recently reported observations which led to the conclusion that women who used oral contraceptives had an increased risk of myocardial infarction (Mann et al., 1975a, b). The observations were made as part of a study -of the causes of myocardial infarction in young women, but they could not all be examined in detail because of shortage of space. We report here, therefore, the results relating to risk factors other than the use of oral contraceptives, and the extent to which they operate independently.

\section{Patients and Methods}

The study was limited to married women under 45 years of age who had been discharged after inpatient treatment for myocardial infarction in three of the hospital regions of England (NorthWest Metropolitan, Oxford, and Wessex) during the years 1968-72, and a corresponding group of control patients selected at random from hospital diagnostic indexes and treated for other conditions (Table I). The methods used for selecting the
TABLE I

MEDICAL AND SURGICAL CONDITIONS IN CONTROII

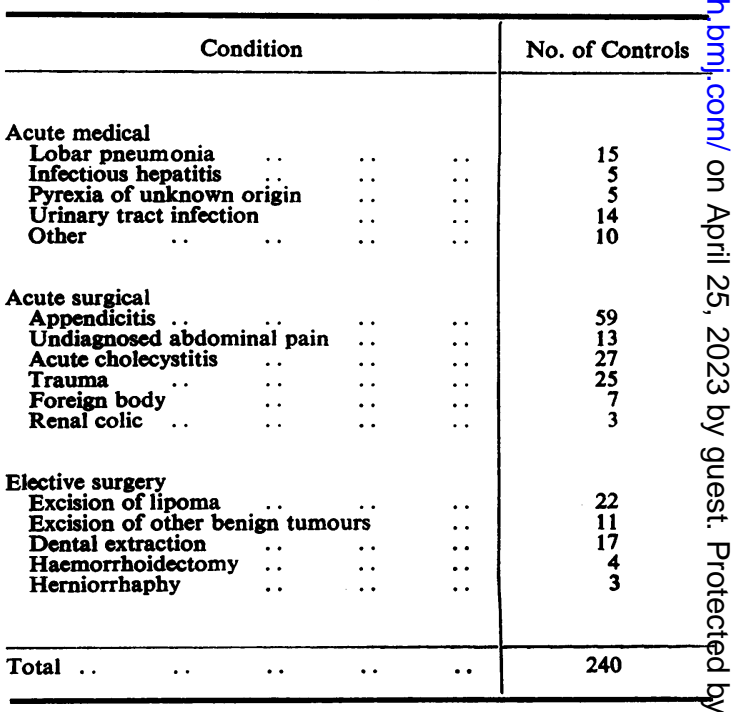


patients and the investigation procedures have been described in detail previously (Mann and Thorogood, 1975; Mann et al., 1975a, b). In brief, 80 myocardial infarction patients were identified and three control patients were matched individually with each of them for age, marital status, hospital, and year of admission. A further 25 infarction patients had died while in hospital or subsequently. Only limited information could be obtained about these patients and for this reason and because the characteristics of women who died had been considered in detail in another publication (Mann and Inman, 1975) they were excluded from the present study. Questionnaires were designed to obtain information about the patients' medical, obstetric, social, family, and contraceptive histories before their relevant admission to hospital and most of the patients also had personal interviews in their homes. All the interviews were carried out by two research assistants, one working in the North-West Metropolitan and Oxford regions, and the other in the Wessex region. Patients who had moved to inaccessible areas or who refused to see the interviewer were sent questionnaires by post. In a few instances, when no reply was obtained, the general practitioner was asked to provide the desired information. All information was collected during 1973. Altogether, information was obtained on 77 infarct patients and 207 controls; the remaining three infarct patients and 33 controls could not be traced. Fasting blood samples were obtained from 52 infarct patients and 112 control patients, and lipid analyses carried out as described previously (Mann and Thorogood, 1975). All blood samples were obtained at least six months after the index hospital admission.

The attributes found to be associated with myocardial infarction had each to be reduced to two categories for the purposes of multivariate analysis and have therefore been defined as follows for the calculation of standardized relative risk estimates. In each case the characteristic was recorded as present or absent:

1. Cigarette smoking: the smoking of $\mathbf{1 5}$ or more cigarettes per day.

2. Hypertension and pre-eclamptic toxaemia: a clear history of drug treatment or hospital admission specifically for the conditions.

3. Diabetes: a medical diagnosis of the condition followed by treatment with insulin, oral hypoglycaemic agents, or diet.

4. Obesity: consultation with a doctor because of obesity.
5. Previous psychiatric history: hospital treatment for a psychiatric condition, or regular drug treatment from a general practitioner.

6. Type II hyperlipoproteinaemia: type IIa hyperlipoproteinaemia (cholesterol $6.9 \mathrm{mmol} / \mathrm{l}$ $(267 \mathrm{mg} / 100 \mathrm{ml})$ or more)* or IIb (cholesterol $6.9 \mathrm{mmol} / 1$ or more and triglyceride 2.3 $\mathrm{mmol} / 1 \mathrm{l}(207 \mathrm{mg} / 100 \mathrm{ml})$ or more).

7. Oral contraceptive use: use of oral contraceptives during the month before the index admission.

The standardized relative risk estimates and summary $\chi^{2}$ values were calculated by an exact maximum likelihood method (Miettinen, 1970).

\section{RESULTS}

The results presented here refer to all the attributes found to be associated with myocardial infarction. They are based on the consolidated findings in the three regions and, with the exception of the data for serum lipids, reflect the situation regarding the presence or absence of the various risk factors before the index admission. Information was sought from each patient about all the items included in the study but a response was not always obtained. When it had to be obtained from the general practitioner it was not always complete; for example, the doctor might have known that his patient had been treated for hypertension without knowing whether she smoked. The results for the different items therefore relate to different totals. With the exception of blood lipid analyses all the totals varied between $86 \%$ and $96 \%$ of the patients with infarction and between $76 \%$ and $92 \%$ of the control patients.

Obesity and a previous psychiatric history are considered first since these factors appeared to be secondarily associated with infarction. They need not therefore be regarded as possible confounding variables when considering the other factors.

\section{OBESITY}

Eighteen (24.3\%) of the 74 infarction patients and $20(10.2 \%)$ of the 197 controls $(P<0.01)$ reported that they had consulted a doctor because of obesity. The increased risk in these women was calculated to be $3 \cdot 4: 1$. Table II shows that this risk is markedly reduced after controlling for four other factors, and ceases to be significantly raised.

\footnotetext{
* Lipid abnormalities were classified as recommended by the World Health Organization (a modification of the Fredrickson classification) (Beaumont et al., 1970). The upper limits of normal for both cholesterol and triglyceride were arbitrarily set at twice the standard deviation above the mean for our control population, and the lipoprotein pattern of each patient was examined after serum electrophoresis.
} 
TABLE II

ESTIMATED RELATIVE RISK OF MYOCARDIAL INFARCTION IN PATIENTS RECEIVING TREATMENT FOR OBESITY AFTER STANDARDIZATION FOR POSSIBLE CONFOUNDING VARIABLES

\begin{tabular}{|c|c|c|c|}
\hline Variable Standardized & $\begin{array}{c}\text { Relative } \\
\text { Risk }\end{array}$ & $x^{2}$ & $\begin{array}{c}\text { Significance } \\
\text { Level }\end{array}$ \\
\hline $\begin{array}{l}\text { None . } \\
\text { Cigarette smoking } \ldots \\
\text { Hypertension } \\
\text { Oral contraceptive use } \\
\text { Pre-eclamptic toxaemia } \\
\text { All above variables } \\
\text { simultaneously .. }\end{array}$ & $\begin{array}{l}3 \cdot 4 \\
2 \cdot 8 \\
2 \cdot 4 \\
3 \cdot 0 \\
2 \cdot 3 \\
1 \cdot 8\end{array}$ & $\begin{array}{l}9 \cdot 3 \\
6 \cdot 4 \\
4 \cdot 6 \\
6 \cdot 7 \\
3 \cdot 8 \\
1 \cdot 7\end{array}$ & $\begin{array}{c}\mathrm{P}<0.01 \\
\mathrm{P}<0.02 \\
\mathrm{P}<0.05 \\
\mathrm{P}<0.01 \\
\mathrm{NS} \\
\mathrm{NS}\end{array}$ \\
\hline
\end{tabular}

\section{Previous Psychiatric History}

Table III shows the number of infarction and control patients who had been treated for a psychiatric complaint before their index hospital admission. A greater frequency of treatment for psychiatric disturbance was shown by both hospital admission $(8 \cdot 1 \%$ against $2 \cdot 0 \%)$ and regular drug treatment from a general practitioner for a primary psychiatric complaint $(10.8 \%$ against $6 \cdot 1 \%)$. Other but less clear evidence of psychiatric disturbance (regular visits to a general practitioner, without the prescription of drugs) was also more common in the infarction group $(6 \cdot 8 \%$ against $2.6 \%)$. The relative risk of developing myocardial infarction in women who had been in hospital because of a psychiatric condition compared with women who reported no treatment for a psychiatric illness is estimated from these figures to be $4 \cdot 7: 1$ and for

TABLE III

TREATMENT FOR PSYCHIATRIC ILLNESS IN WOMEN WHO SURVIVED A MYOCARDIAL INFARCTION AND CONTROL PATIENTS (PERCENTAGES IN PARENTHESES)

\begin{tabular}{l|cc|cc}
\hline & \multicolumn{4}{|c|}{ No. of Patients } \\
\cline { 2 - 5 } & \multicolumn{2}{|c|}{$\begin{array}{c}\text { Myocardial } \\
\text { Infarction }\end{array}$} & \multicolumn{2}{|c}{ Controls } \\
\hline $\begin{array}{l}\text { Po previous history } \\
\begin{array}{l}\text { Hospital admission } \\
\text { for psychiatric } \\
\text { condition }\end{array}\end{array}$ & 55 & $(74 \cdot 3)$ & 175 & $(89 \cdot 3)$ \\
$\begin{array}{l}\text { Regular drug treat- } \\
\text { ment from general } \\
\text { practitioner for } \\
\text { psychiatric condition }\end{array}$ & 6 & $(8 \cdot 1)$ & 4 & $(2 \cdot 0)^{*}$ \\
$\begin{array}{l}\text { Less clear previous } \\
\text { psychiatric history }\end{array}$ & 5 & $(10 \cdot 8)$ & 12 & $(6 \cdot 1)^{*}$ \\
\hline Total .. & 74 & $(6 \cdot 8)$ & 5 & $(2 \cdot 6)$ \\
\hline Not known &.. & 3 & 196 \\
\hline
\end{tabular}

* Comparison between proportions of patients who had been admitted to hospital or received regular drug treatment from their general practitioner.

$x_{1}^{2}=5 \cdot 1, P<0.025$ those who received regular drug treatment from $\frac{1}{\Phi}$ their general practitioner $2 \cdot 1: 1$. (The psychiatric? diagnoses and details of drug treatment are not $\vec{F}$ available for these patients.) The relative risk of developing myocardial infarction for women in등 either of these two categories is $2 \cdot 8: 1$. After $\bar{c}$. standardization for other risk factors (Table IV) this estimate was reduced to $1 \cdot 6$.

TABLE IV

ESTIMATED RELATIVE RISK OF MYOCARDIAL INFARCTION IN PATIENTS RECEIVING TREATMENT FOR A PSYCHIATRIC ILLNESS AFTER STANDARDIZATION FOR POSSIBLE CONFOUNDING VARIABLES

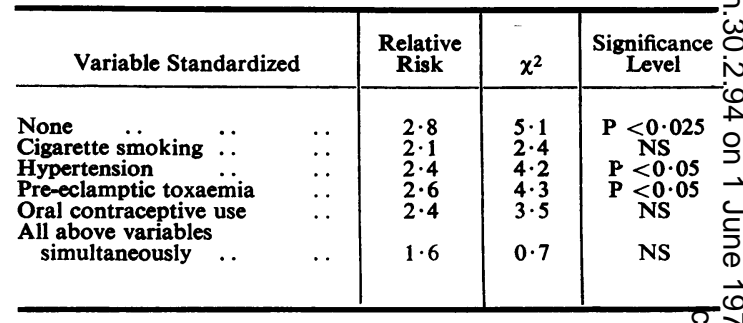

\section{Cigarette Smoking}

The cigarette smoking habits of the infarctions and control patients are shown in Table V. In comparison with non-smokers the relative risko increased from $1 \cdot 8: 1$ in women smoking fewero than 15 cigarettes a day, to $4 \cdot 3: 1$ in women smoking 15-24 a day, and 18.5:1 in womeng smoking 25 or more a day. The relative risk in the combined group of women smoking 15 or more़e

\section{TABLE V}

CIGARETTE SMOKING HABITS OF MYOCARDIAP INFARCTION AND CONTROL PATIENTS (PERCENTAGES IN PARENTHESES)

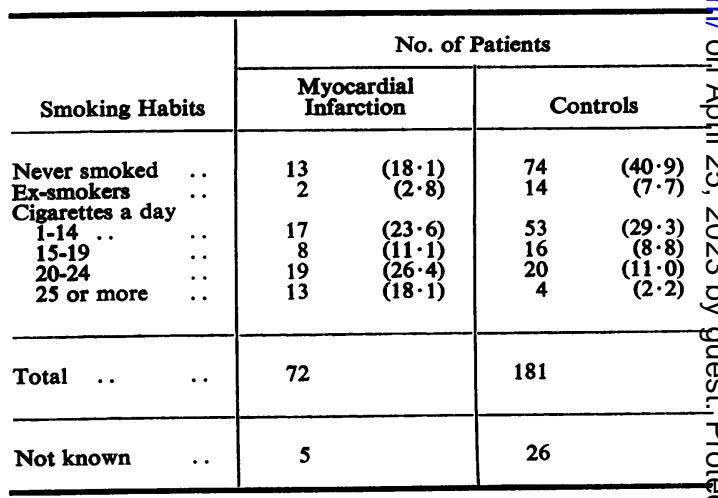

Test for linear trend amongst all smoking categories:

$$
x_{1}^{2}=35.9, P<0.001
$$


TABLE VI

ESTIMATED RELATIVE RISK OF MYOCARDIAL INFARCTION IN PATIENTS CURRENTLY SMOKING MORE THAN 15 CIGARETTES A DAY AFTER STANDARDIZATION FOR POSSIBLE CONFOUNDING VARIABLES

\begin{tabular}{|c|c|c|c|c|}
\hline \multicolumn{2}{|c|}{ Variable Standardized } & $\begin{array}{c}\text { Relative } \\
\text { Risk }\end{array}$ & $x^{2}$ & $\begin{array}{c}\text { Significance } \\
\text { Level }\end{array}$ \\
\hline $\begin{array}{l}\text { None . } \\
\text { Hypertension } \\
\text { Pre-eclamptic toxaemia } \\
\text { Oral contraceptive use } \\
\text { All above variables } \\
\text { simultaneously .. }\end{array}$ & $\begin{array}{l}. . \\
\because \\
\cdots \\
. .\end{array}$ & $\begin{array}{l}5 \cdot 7 \\
4 \cdot 2 \\
4 \cdot 4 \\
4 \cdot 0 \\
4 \cdot 0\end{array}$ & $\begin{array}{l}18 \cdot 7 \\
15 \cdot 0 \\
15 \cdot 5 \\
13 \cdot 2 \\
11 \cdot 6\end{array}$ & $\begin{array}{l}P<0.001 \\
P<0.001 \\
P<0.001 \\
P<0.001 \\
P<0.001\end{array}$ \\
\hline
\end{tabular}

cigarettes a day as compared with non-smokers is calculated from these data to be 5.7:1 and Table VI gives estimates of this relative risk after allowing for the effect of other risk factors. A fourfold increase in risk remains even after standardization for all three factors simultaneously. Possible confounding by diabetes has not been considered because of the very small number of patients who were diabetic. Type II hyperlipoproteinaemia has also not been included because lipid results were not available for an appreciable number of infarction and control patients, and inclusion of this risk factor would have greatly reduced the number of cases which could be used in the calculation. The exclusion of hyperlipoproteinaemia should not matter as cigarette smoking habits and serum cholesterol levels do not appear to be related (Truswell and Mann, 1972).

\section{Hypertension and Pre-Eclamptic Toxaemia}

Blood pressure readings were not available for individual patients and hypertension and preeclamptic toxaemia were defined as being present if the women reported having received hospital or drug treatment for either of these conditions. Eleven of the 74 infarction patients $(14.9 \%)$ as compared with six of the 197 controls $(3 \cdot 1 \%)$ $(\mathrm{P}<0.01)$ received drug treatment specifically for hypertension and the relative risk in women who had received treatment as compared with those who had not is calculated to be $5 \cdot 6: 1$. Nine of the 11 patients who had been treated for hypertension before their hospital admission for myocardial infarction also reported that they had received treatment for pre-eclamptic toxaemia during one or more pregnancies, and standardization for pre-eclampsia reduced the estimated risk by nearly two-thirds (Table VII). Further standardization for cigarette smoking and the current use of oral contraceptives had only a trivial effect. Diabetes and type II hyperlipoproteinaemia are again not considered, for the reasons given previously.
TABLE VII

ESTIMATED RELATIVE RISK OF MYOCARDIAL INFARCTION IN PATIENTS RECEIVING DRUG THERAPY FOR HYPERTENSION AFTER STANDARDIZATION FOR POSSIBLE CONFOUNDING VARIABLES

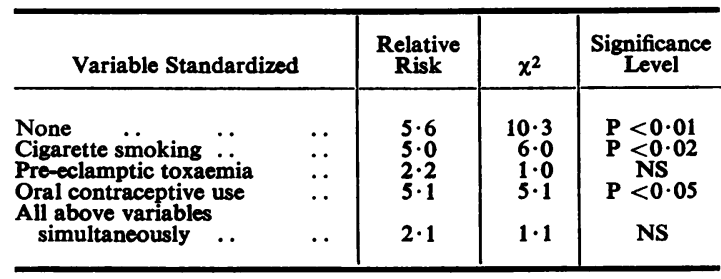

Treatment for pre-eclamptic toxaemia during one or more pregnancies was reported by 21 of the 74 infarct patients $(28.4 \%)$ and 22 of the 196 controls $(11 \cdot 2 \%)(P<0 \cdot 01)$, representing a threefold increase in risk among women treated for the condition. This risk does not appear to be appreciably altered after standardization for hypertension or for other risk factors (Table VIII). The interpretation of these unexpected results is discussed later.

TABLE VIII

ESTIMATED RELATIVE RISK OF MYOCARDIAL INFARCTION IN PATIENTS RECEIVING TREATMENT FOR PRE-ECLAMPTIC TOXAEMIA AFTER STANDARDIZATION FOR POSSIBLE CONFOUNDING VARIABLES

\begin{tabular}{|c|c|c|c|}
\hline Variable Standardized & $\begin{array}{l}\text { Relative } \\
\text { Risk }\end{array}$ & $x^{2}$ & $\begin{array}{c}\text { Significance } \\
\text { Level }\end{array}$ \\
\hline $\begin{array}{l}\text { None } \\
\text { Cigarette smoking } \ldots \\
\text { Hypertension } \\
\text { Oral contraceptive use } \\
\text { All above variables } \\
\text { simultaneously } \quad . .\end{array}$ & $\begin{array}{l}3 \cdot 0 \\
3 \cdot 8 \\
2 \cdot 8 \\
2 \cdot 8 \\
2 \cdot 8\end{array}$ & $\begin{array}{r}10 \cdot 5 \\
9 \cdot 6 \\
6 \cdot 4 \\
6 \cdot 2 \\
4 \cdot 4\end{array}$ & $\begin{array}{l}P<0.01 \\
P<0.01 \\
P<0.02 \\
P<0.02 \\
P<0.05\end{array}$ \\
\hline
\end{tabular}

\section{DiABeTeS}

Insulin (in two cases) or oral hypoglycaemic agents (in three cases) had been prescribed for five of the 75 infarct patients $(6 \cdot 8 \%)$ and an oral hypoglycaemic agent for one of the 197 controls $(0.5 \%)(P=0.007)$, so that the increased risk to patients receiving treatment for diabetes as compared with patients not being treated for this condition is estimated to be 14-fold. Blood glucose was not measured in individual cases and these figures are likely to underestimate the frequency of diabetes in both groups. One or more of the other risk factors was present in four of the five infarct patients who had been treated for diabetes. In view of considerable other evidence (Garcia et al., 1974) diabetes must be considered a risk factor for myocardial infarction, but it may be that its effect is 
relatively small when other factors are absent, as appears to be the case with oral contraceptives (Mann et al., 1975a). It has not been included in the previous tables since the small number of affected patients could not have confounded the other associations.

\section{TYPE II HYPERLIPOPROTEINAEMIA}

Data concerning serum lipids were available for $67.5 \%$ of the infarct patients and $54.1 \%$ of the controls. The results for the North-West Metropolitan and Oxford regions have been considered in detail elsewhere (Mann and Thorogood, 1975). The mean cholesterol and triglyceride levels for the infarct and control patients remained virtually unchanged after the addition of the few samples obtained in the Wessex region. Type IIa or IIb hyperlipoproteinaemia was present in $21(40 \cdot 3 \%)$ of the patients with infarction and two $(1.8 \%)$ of the controls. Type IV hyperlipoproteinaemia, however, occurred with almost equal frequency in both groups $(5 \cdot 8 \%$ and $8.0 \%$ respectively). The relative risk of myocardial infarction in women with one of the two varieties of type II hyperlipoproteinaemia compared with women in whom lipid levels are known and regarded as normal is calculated from these data to be $27 \cdot 1: 1$. Table IX suggests that associations with other risk factors may explain some of this risk; but a substantial risk is still apparent even after controlling for four other factors simultaneously.

TABLE IX

ESTIMATED RELATIVE RISK OF MYOCARDIAL INFARCTION IN PATIENTS WITH TYPE IA OR B HYPERLIPOPROTEINAEMIA AFTER STANDARDIZATION FOR POSSIBLE CONFOUNDING VARIABLES

\begin{tabular}{|c|c|c|c|c|}
\hline Variable Standardized & & $\underset{\text { Risk }}{\text { Relative }}$ & $x^{2}$ & $\underset{\text { Level }}{\text { Significance }}$ \\
\hline $\begin{array}{l}\text { None } \\
\text { Hypertension .. } \\
\text { Pre-eclamptic toxaemia } \\
\text { Cigarette smoking .. } \\
\text { Oral contraceptive use } \\
\text { All above factors } \\
\text { simultaneously ... }\end{array}$ & $\begin{array}{l}\cdots \\
\cdots \\
\cdots \\
\cdots \\
\cdots\end{array}$ & $\begin{array}{l}27 \cdot 1 \\
16 \cdot 3 \\
18 \cdot 9 \\
23 \cdot 6 \\
25 \cdot 1 \\
15 \cdot 8\end{array}$ & $\begin{array}{l}31 \cdot 5 \\
17 \cdot 4 \\
18 \cdot 6 \\
16 \cdot 2 \\
29 \cdot 7 \\
14 \cdot 7\end{array}$ & $\begin{array}{l}\mathbf{P}<0.001 \\
\mathbf{P}<0.001 \\
\mathbf{P}<0.001 \\
\mathbf{P}<0.001 \\
\mathbf{P}<0.001 \\
\mathbf{P}<0.001\end{array}$ \\
\hline
\end{tabular}

\section{OTHER FACTORS}

No statistically significant differences were found between the infarct patients and their controls with respect to social class, country of origin, parity, and menopausal state at the time of admission (Table $\mathrm{X}$ ). No appreciable difference was recorded between the groups in the frequency of previous renal or thyroid disease.
TABLE X

SOCIAL CLASS, ORIGIN, PARITY, AND MENOPAUSAE STATE OF MYOCARDIAL INFARC'TION AND CONTROI

\begin{tabular}{|c|c|c|c|c|}
\hline \multirow[b]{3}{*}{$\begin{array}{l}\text { Social class } \\
\begin{array}{l}\text { I-II } \\
\text { III }\end{array} \\
\text { IV-V } \\
\text { Widowed or divorced }\end{array}$} & \multicolumn{4}{|c|}{ No. and Percentage of Patients } \\
\hline & \multicolumn{2}{|c|}{$\begin{array}{l}\text { Myocardial } \\
\text { Infarction }\end{array}$} & \multicolumn{2}{|c|}{ Controls } \\
\hline & $\begin{array}{r}22 \\
29 \\
10 \\
5\end{array}$ & $\begin{array}{l}(33 \cdot 3) \\
(43 \cdot 9) \\
(15 \cdot 2) \\
(7 \cdot 6)\end{array}$ & $\begin{array}{l}60 \\
56 \\
28 \\
13\end{array}$ & $\begin{array}{l}(38.2) \\
(35.7) \\
(17.8) \\
(8 \cdot 3)\end{array}$ \\
\hline Total $\ldots$ & 66 & & 157 & \\
\hline $\begin{array}{l}\text { Origin } \\
\text { United Kingdom } \\
\text { Commonwealth } \\
\text { Europe } \quad . . \\
\text { Asia .. } \quad . .\end{array}$ & $\begin{array}{r}57 \\
4 \\
5 \\
1\end{array}$ & $\begin{array}{r}(85 \cdot 1) \\
(6 \cdot 0) \\
(7 \cdot 5) \\
(1 \cdot 5)\end{array}$ & $\begin{array}{r}134 \\
7 \\
14 \\
2\end{array}$ & $\begin{array}{r}(85 \cdot 4) \\
(4 \cdot 5) \\
(8 \cdot 9) \\
(1 \cdot 3)\end{array}$ \\
\hline Total $\ldots$ & 67 & & 157 & \\
\hline \multirow{2}{*}{$\begin{array}{l}\text { Parity } \\
\text { Nulliparous } \\
1-3 \text { pregnancies } \\
\text { More than } 3 \\
\text { pregnancies .. }\end{array}$} & $\begin{array}{r}8 \\
51\end{array}$ & $\begin{array}{l}(11 \cdot 0) \\
(69 \cdot 9)\end{array}$ & $\begin{array}{r}17 \\
113\end{array}$ & $\begin{array}{r}(8.9) \\
(58 \cdot 9)\end{array}$ \\
\hline & 14 & $(19 \cdot 2)$ & 62 & $(32 \cdot \sqrt[3]{J}$ \\
\hline Total $\quad$. & 73 & & 192 & \\
\hline $\begin{array}{c}\text { Menopausal state } \\
\text { Still menstruating } \\
\text { Post-menopausal }\end{array}$ & $\begin{array}{r}65 \\
8\end{array}$ & $\begin{array}{l}(89 \cdot 0) \\
(11 \cdot 0)\end{array}$ & $\begin{array}{r}167 \\
17\end{array}$ & $\begin{array}{r}(90 \cdot 8) \\
(9 \cdot 2)\end{array}$ \\
\hline Total $\ldots$ & 73 & & 184 & \\
\hline
\end{tabular}

\section{INTERACTION OF FACTORS}

In an earlier publication based on the findings two regions (Mann et al., 1975a) it was suggeste that the combined effect of risk factors was synergistic. Table XI shows patients in the three regions known to have had various numbers of risk factors. For this purpose we have regardet treatment for hypertension or pre-eclamptic tox aemia as contributing one risk factor (see Dișer cussion).* On this basis the relative risk in comparison with that in patients not known to have any risk factors increased from $4: 1$ in women with one factor, to $20: 1$ in women with two factors, and 128:1 in women with three or more factors. The quantitative effect of individuas combinations of risk factors can be determined only by the study of a very large number $\&$

*Information on the presence of one or more factors was n\& obtained for a few patients, and lipid analyses were carried out 9 . only $68 \%$ of the patients with infarction, so that the number exposed to one risk factor or none at all is likely to be even smale than appears from Table XI. 
TABLB XI

NUMBERS OF MYOCARDIAL INFARCTION AND CONTROL PATIENTS WHO HAD VARIOUS NUMBERS OF RISK FACTORS (PERCENTAGES IN PARENTHESES)

\begin{tabular}{|c|c|c|c|c|}
\hline Risk Factors & \multicolumn{2}{|c|}{$\begin{array}{l}\text { Myocardial } \\
\text { Infarction }\end{array}$} & \multicolumn{2}{|c|}{ Controls } \\
\hline $\begin{array}{l}\text { None .. } \\
\text { One } \\
\text { Type II hyper- } \\
\text { lipoproteinaemia } \\
\text { Hypertension or } \\
\text { pre-eclamptic } \\
\text { toxaemia } \\
\text { Cigarette smoiking } \\
\text { (15 or more a day) } \\
\text { Diabetes } \\
\text { Current oral .. } \\
\text { contraceptive use } \\
\text { Two . } \quad . . \\
\text { Three or more } \quad . .\end{array}$ & $\begin{array}{r}12 \\
1 \\
4 \\
20 \\
14\end{array}$ & $\begin{array}{r}(18 \cdot 9) \\
(5 \cdot 4) \\
(6 \cdot 8) \\
(16 \cdot 2) \\
(1 \cdot 4) \\
(5 \cdot 4) \\
(27 \cdot 0) \\
(18 \cdot 9)\end{array}$ & $\begin{array}{r}128 \\
1 \\
19 \\
33 \\
0\end{array}$ & $\begin{array}{r}(64 \cdot 0) \\
(0 \cdot 5) \\
(9 \cdot 5) \\
(16 \cdot 5) \\
\\
(4 \cdot 5) \\
(4 \cdot 5) \\
(0 \cdot 5)\end{array}$ \\
\hline Total & 74 & & 200 & \\
\hline
\end{tabular}

patients, but these risk estimates derived from the data in Table XI tend to confirm the earlier suggestion that the combined effect of the factors is synergistic.

\section{Discussion}

The first reports of our study dealt with the role of oral contraceptives as a risk factor for myocardial infarction and suggested that the use of these preparations increased the risk of myocardial infarction independently of other factors. Further analysis now shows that the same applies to several of the other established factors, when present in women under 45 years of age. An apparent increase in the relative risk estimates might have resulted if one of the factors considered had been beneficial to survival from myocardial infarction but did not contribute to incidence. However, the similar results obtained with regard to oral contraceptive use and treatment for hypertension and diabetes in the investigation of deaths from myocardial infarction lead us to believe that this is unlikely to have confounded the findings of the present study.

The persistence of a greatly increased risk of myocardial infarction in heavy cigarette smokers and in women with type II hyperlipoproteinaemia after standardizing for possible confounding variables is not surprising. Hypercholesterolaemia and heavy cigarette smoking have been shown to be important risk factors in young men in many studies (for example, Dolder and Oliver, 1975), and in the one study of myocardial infarction in women which included an appreciable number under 45 years of age (Oliver, 1975).
Hypertension is a well recognized risk factor for myocardial infarction in both sexes (Bengtsson, 1973; Dolder and Oliver, 1975; Oliver, 1975), and it is surprising that the increased risk was so greatly reduced after standardizing for pre-eclamptic toxaemia, while standardizing for hypertension had only little effect on the estimated risk from toxaemia. The simplest explanation of this anomaly is that it is an artefact due to diagnostic confusion. Women who require treatment for hypertension under 45 years of age are likely to have been hypertensive during a preceding pregnancy and, if the hypertension had not been recognized previously, are liable to be diagnosed as having had toxaemia irrespective of whether they had any persistent hypertension or not. A more detailed medical history was available for only six of the nine infarct patients reporting treatment for hypertension and pre-eclampsia, and in four of these patients the pre-eclampsia had been diagnosed during a pregnancy before the treatment for hypertension had been started. We do not know, however, what their blood pressures were before the intervention of pregnancy.

The precise relationship between pre-eclampsia and hypertension is not clear (Chesley, Annitto, and Cosgrove, 1968) and the present investigation does not enable us to disentangle their relative roles in predisposing to myocardial infarction. It certainly does not exclude hypertension as a risk factor but it is of interest that pre-eclampsia does appear to be associated with an independent increased risk.

The role of obesity in ischaemic heart disease has long been disputed. In a detailed review, Keys et al. (1972) concluded that the apparently increased risk in obese men could be totally explained by an association with other risk factors. Our data suggest that this conclusion may also apply in young women.

The finding of an association between myocardial infarction and previous treatment for a psychiatric complaint either in hospital or by a general practitioner was unexpected. The fact that the increased risk was greatly reduced after standardization for other factors suggests that the association is secondary rather than causal. It may be, however, that some risk arises because of an association between personality type and the development of myocardial infarction (Jenkins, Rosenman, and Zynanski, 1974), or because of an effect of the drugs used to treat the complaints. Tricyclic antidepressants, for instance, have been associated with sudden and unexpected death in patients suffering from cardiac disease (Coull et al., 1970). Alternatively, non-specific symptoms occurring 
before an acute myocardial infarction may result in patients being treated for such symptoms by psychotropic drugs.

We are grateful to the consultants and general practitioners who allowed us to study patients under their care and provided information, to the medical records officers of the hospitals and their staff who gave willing help in many ways, and to the patients who gave up their time to answer our questions. We are also grateful to Miss Carol Powell for carrying out the interviews in the Wessex region. Financial assistance was received from the Department of Health and Social Security.

Requests for reprints: J. I. Mann, Department of Social and Community Medicine, University of Oxford.

\section{REFERENCES}

Beaumont, J. L., Carlson, L. A., Cooper, G. R., Fejfar, Z., Fredrickson, D. S., and Strasser, T. (1970). Classification of hyperlipidaemias and hyperlipoproteinaemias. Bull. Wld Hlth Org., 43, 891.

Bengtsson, C. (1973). Ischaemic heart disease in women. Acta med. scand., Suppl. 549.

Chesley, L. C., Annitto, J. E., and Cosgrove, R. A. (1968). Long term follow-up study of eclamptic women. Amer. J. Obstet. Gynec., 101, 886.

Coull, D. C., Crooks, J., Dingwall-Fordyce, I., ScotT, A. M., and WeIR, R. D. (1970). Amitriptyline and cardiac disease. Lancet, 2, 590.

Dolder, M. A. and OLIVER, M. F. (1975). Myocardial infarction in young men. Brit. Heart J., 37, 493.
Garcia, M. J., McNamara, P. M., Gordon, T., and KANNELL, W. B. (1974). Morbidity and mortality in? diabetics in the Framingham population. Diabetes 23, 105.

Jenkins, C. D., Rosenman, R. H., and Zynanski, S. J⿸厂巳一 (1974). Prediction of clinical coronary heart disease bo a test for the coronary prone behavior pattern. News Engl. J. Med., 290, 1271.

Keys, A., Aravanis, C., Blackburn, H., van Buchemon F. S. P., Buzina, R., DJordjevic, B. S., Fidanza, F. $\vec{P}$ Karvonen, M. J., Menotti, A., Puddu, V., and TAYLOR, H. L. (1972). Coronary heart disease-over $\vec{\omega}$ weight and obesity as risk factors. Ann. intern. Med. 77, 15.

ManN, J. I. and INMaN, W. H. W. (1975). Oral contra? ceptives and death from myocardial infarction. Brito med. J., 2, 245.

— and THOROGOOD, M. (1975). Serum lipids in youngs female survivors of myocardial infarction. Brit. Hearg J., 37, 790.

—, Vessey, M. P., Thorogood, M., and Doll, $\mathrm{R}_{\odot}^{\complement}$ (1975a). Myocardial infarction in young women wit special reference to oral contraceptive practice. Brit. med. J., 2, 241.

WATERs, W. E., Thorogood, M., and Power 80 \% (1975b). Oral contraceptives and myocardial infarctiop in young women: a further report. Brit. med. J., 3,

MieTtinen, O. S. (1970). Estimate of relative risk from individually matched series. Biometrics, 26, 75.

OLIVER, M. F. (1975). Ischaemic heart disease in youn\& women. Brit. med. J., 4, 253.

Truswell, A. S. and MANN, J. I. (1972). The epidemi ology of serum lipids in southern Africa. Atherosclera sis, 16, 15. 